\title{
Implementasi Bank Sampah Pada ST. Kerta Budi Luhur untuk Pengelolaan Sampah Organik dan Anorganik
}

\author{
I Nyoman Rudy Hendrawan ${ }^{1}$, Deviana ${ }^{2}$, I Made Arya Budhi Saputra ${ }^{3 *}$ \\ 1,2,3 Sistem Informasi, ITB STIKOM Bali \\ 1'rudyhendrawan@stikom-bali.ac.id, 2deviana@ stikom-bali.ac.id, naryabudhi@ stikom-bali.ac.id
}

\begin{abstract}
ST. Kertha Budi Luhur is the youth organization of the Kayumas Kelod traditional banjar which was founded around 1995. One of the social activities of the Sekaa Teruna is to focus on environmental and waste issues. Related to the issue of waste ST. Kertha Budi Luhur plans to establish a waste bank. The waste bank is an alternative solution that can be done by the community in terms of waste management or management. Waste banks can increase public participation to care more about the waste they produce daily, besides that, with the existence of waste banks, the community can get economic value feedback. Therefore, in this community service, socialization and training were carried out on how to form a waste bank. This community service activity is broadly divided into initial socialization activities aimed at providing initial information about waste banks and technical training activities aimed at providing a more detailed explanation of the waste bank operations, from sorting waste to working with garbage collectors. Increased awareness of waste management by $85 \%$ of ST members Kertha Budi Luhur after the training.
\end{abstract}

Keywords: ST. Kerta Budhi Luhur, Garbage Bank, Training

Abstrak

ST. Kertha Budi Luhur adalah organisasi pemuda banjar adat Kayumas Kelod yang telah berdiri dari sekitar tahun 1995. Kegiatan sosial dari Sekaa Teruna ini, salah satunya adalah fokus pada isu lingkungan dan sampah. Terkait dengan isu sampah ST. Kertha Budi Luhur berencana untuk mendirikan bank sampah. Bank sampah adalah solusi alternatif yang dapat dilakukan masyarakat dalam hal pengelolaan atau manajemen sampah. Bank sampah dapat meningkatkan partisipasi masyarakat untuk lebih peduli kepada sampah yang dihasilkannya sehari-hari, disamping itu dengan keberadaan bank sampah masyarakat dapat mendapatkan timbal balik nilai ekonominya. Oleh karena itu pada pengabdian masyarakat ini dilaksanakan sosialisasi dan pelatihan tentang cara pembentukan bank sampah. Kegiatan pengabdian ini secara garis besar dibagi menjadi kegiatan sosialisasi awal yang bertujuan untuk memberikan informasi awal mengenai bank sampah dan kegiatan pelatihan teknis bertujuan untuk memberikan penjelasan yang lebih rinci tentang operasional bank sampah, mulai dari memilah sampah sampai dengan bekerja sama dengan pengepul sampah. Peningkatan kesadaran manajemen pengelolaan sampah sebesar 85\% anggota ST. Kertha Budi Luhur setelah dilakukannya pelatihan.

Kata Kunci: ST. Kerta Budhi Luhur, Bank Sampah, Pelatihan

*Penulis Korespondensi: I Made Arya Budhi Saputra

\section{PENDAHULUAN}

Sekaa teruna-teruni merupakan organisasi pemuda yang secara struktur organisasi adat di provinsi Bali berada di bawah pengawasan banjar adat. Anggota dari sekaa teruna-teruni pada umumnya adalah masyarakat yang berada diusia sekolah ataupun yang belum menikah. (Padmiari, I.A, Sugiani, Pande
Putu, Gumala, Ni Made, Provinsi and Klungkung, 2015) Salah satu dari sekaa teruna-teruni yang ada di kota Denpasar adalah Sekaa Teruna Kertha Budi Luhur (dalam bagian selanjutnya akan disebut ST. Kertha Budi Luhur).

ST. Kertha Budi Luhur (Gambar 1) adalah organisasi pemuda banjar adat Kayumas Kelod yang telah berdiri dari sekitar tahun 1995. Seperti halnya sekaa teruna-teruni lainnya, 
kegiatan rutin dari organisasi ini adalah pembuatan ogoh-ogoh untuk menyambut hari raya Nyepi, kegiatan tabuh dan tari adat disetiap upacara keagamaan, dan kegiatan-kegiatan lainnya di bidang sosial. Khusus untuk kegiatan sosial lainnya, salah satunya dari kegiatan ST. Kertha Budi Luhur fokus pada isu lingkungan dan sampah. Sebagai contoh, berdasarkan keterangan dari Putu Eka Darma Putra sebagai ketua sekaa teruna-teruni, pada hari kemerdekaan 17 Agustus 2019 ST. Kertha Budi Luhur beserta masyarakat banjar Kayumas Kelod melaksanakan acara jalan santai yang bersamaan dengan memungut sampah plastik yang ditemui di jalan. (lihat Gambar 2)

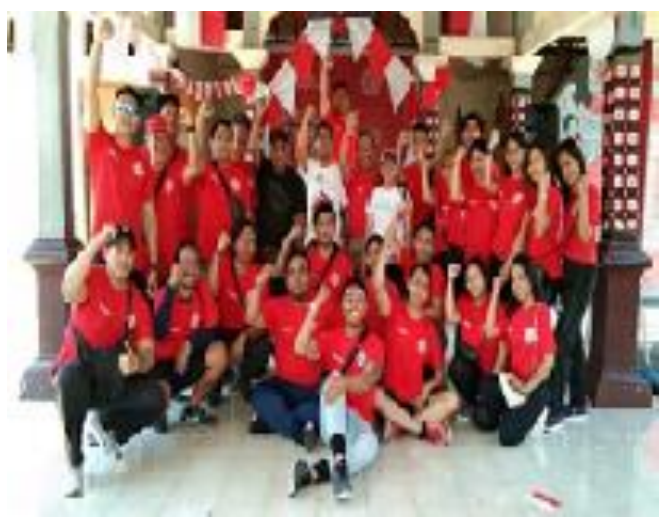

Gambar 1. Anggota ST. Kerta Budi Luhur

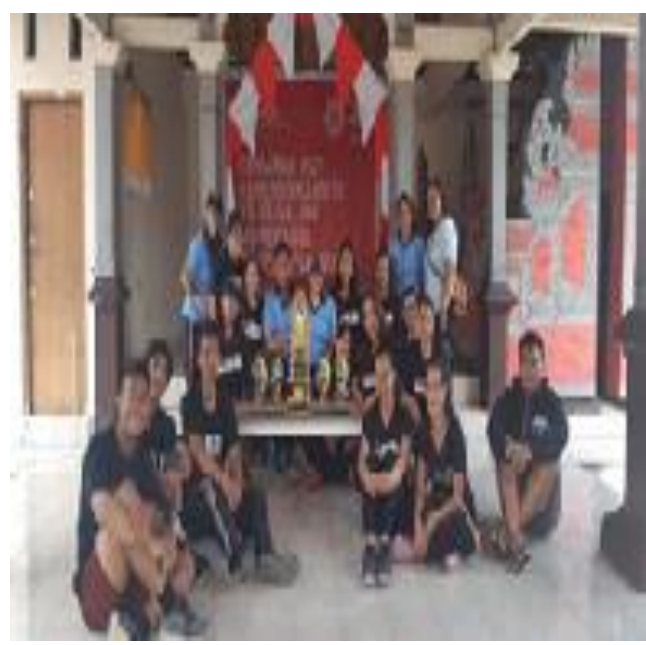

Gambar 2. Anggota ST. Kerta Budi Luhur Memperingati Hari Kemerdekaan

Hal lainnya yang menjadi fokus dari ST. Kertha Budi Luhur berkaitan dengan isu sampah adalah ST. Kertha Budi Luhur berencana untuk mendirikan bank sampah. Bank sampah adalah solusi alternatif yang dapat dilakukan masyarakat dalam hal pengelolaan atau manajemen sampah. Bank sampah dapat meningkatkan partisipasi masyarakat untuk lebih peduli kepada sampah yang dihasilkannya sehari-hari(Asteria and Heruman,
2016) , disamping itu dengan keberadaan bank sampah masyarakat dapat mendapatkan imbal balik nilai ekonominya. Sehingga, bank sampah akan memberikan dampak positif bagi lingkungan dan ekonomi masyarakat sekitar (Utami, 2013).

Berdasarkan analisis situasi di atas maka permasalahan yang akan diatasi pada pengabdian masyarakat ini adalah membantu masyarakat Banjar Kayumas Kelod bersama dengan ST. Kertha Budi Luhur dalam mendirikan dan mengembangkan bank sampah dan mengkampanyekan isu-isu yang terkait dengan menjaga lingkungan dan pengelolaan sampah yang benar melalui media sosial.

Oleh karena itu pada kegiatan pengabdian masyarakat ini dilaksanakan sosialisasi dan pelatihan tentang cara pembentukan bank sampah. Kegiatan ini dilakukan dengan kerja sama bersama dengan mitra, yaitu ST. Kerta Budi Luhur sebagai agen atau representatif dalam kampanye sadar sampah di lingkungannya.

Lokasi Kegiatan nantinya akan dipusatkan pada Banjar Kayumas Kelod, Desa Dangin Puri kota Denpasar. Lokasi berjarak kurang lebih $2 \mathrm{~km}$ dengan menempuh jarak dari ITB STIKOM Bali selama 10 Menit.

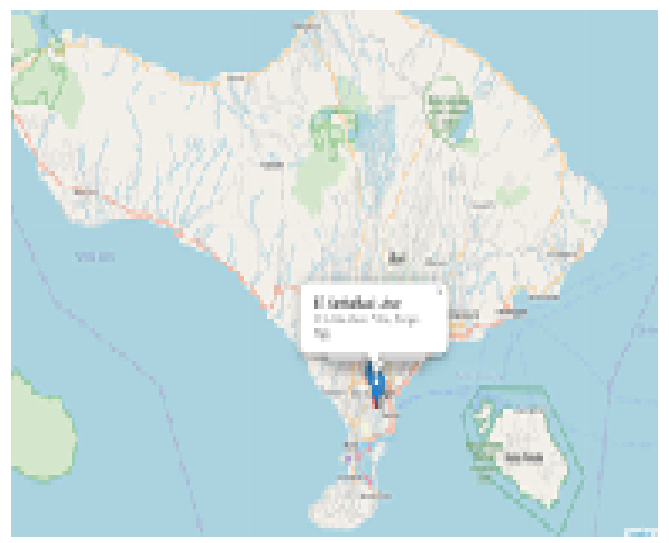

Gambar 3. Peta Lokasi Mitra

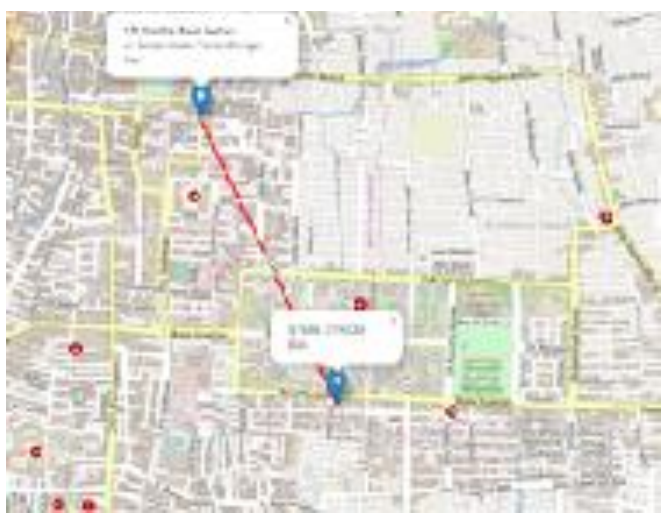

Gambar 4. Lokasi Pengabdian Masyarakat 


\section{METODE}

Berdasarkan analisis situasi dan permasalahan yang telah dipaparkan di bagian sebelumnya, maka solusi yang ditawarkan pada pengabdian masyarakat ini adalah:

1. Sosialisasi awal tentang bank sampah, meliputi definisi dari bank sampah, tujuan dari pembentukan bank sampah, dan juga manfaat yang didapat dari bank sampah baik itu manfaat yang diterima langsung oleh warga banjar dan juga manfaat bagi kelestarian dan kebersihan lingkungan sekitar banjar. Sosialisasi ini akan diberikan kepada seluruh anggota ST. Kertha Budi Luhur dan juga warga banjar Kayumas Kelod. Narasumber dari sosialisasi adalah perusahaan daur ulang sampah.

2. Pelatihan teknis yang ditujukan bagi calon pengurus bank sampah baik itu dari organisasi ST. Kertha Budi Luhur dan juga dari warga banjar, dimana pelatihan ini mencakup tentang bagaimana cara membentuk bank sampah, cara mengelola operasional bank sampah, mulai dari memilah sampah sampai dengan bekerja sama dengan pengepul sampah. Pada tahap ini penulis akan bekerja sama dengan narasumber dari perusahaan daur ulang sampah.

3. Mensosialisasikan tentang kepedulian lingkungan terutama pengelolaan sampah dan juga tata cara pengolahan sampah kepada masyarakat banjar Kayumas Kelod.

4. Mensosialisasikan pengolahan sampah dan pemanfaatan bank sampah sebagai media pengelolaan sampah melalui media sosial yaitu Instagram, Facebook, dan Twitter.

Kegiatan pengabdian masyarakat dapat dilihat pada Gambar 5 dimana kegiatan awal yang dilakukan adalah pembuatan materi sosialisasi dan pelatihan mengenai bank sampah, kemudian dilanjutkan ke tahap pelatihan pengelolaan sampah, hingga ke tahap pelatihan cara pembentukan bank sampah.

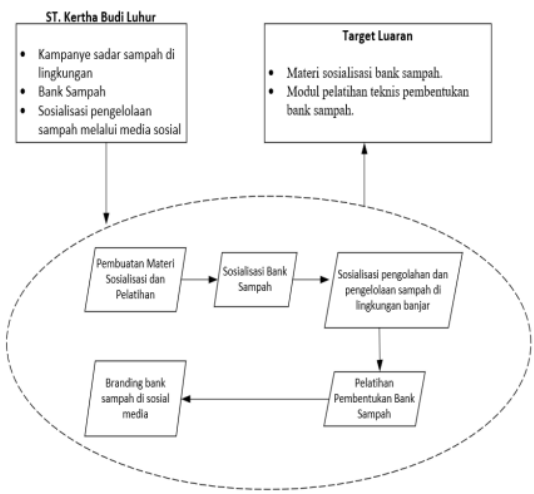

Gambar 5. Alur Kegiatan
Pengabdian masyarakat ini diikuti oleh seluruh anggota ST. Kertha Budi Luhur, dimana seluruh anggota mengikuti seluruh kegiatan yang direncanakan mulai dari sosialisasi mengenai bank sampah, pelatihan pengelolaan sampah rumah tangga, hingga pelatihan cara pembentukan bank sampah. Anggota dari ST. Kertha Budi Luhur ini akan secara aktif ikut dalam kegiatan dimana harapannya adalah seluruh anggota dapat mengetahui bagaimana proses pembentukan bank sampah.

Evaluasi dilakukan berdasarkan bagaimana pemahaman dan tindak lanjut dari mitra setelah dilakukannya kegiatan pengabdian. Mitra diharapkan dapat memahami konsep dari bank sampah, memahami bagaimana cara mengelola sampah, hingga mengetahui cara untuk membentuk bank sampah.

Keberlanjutan program dari pengabdian adalah melakukan pengembangan terhadap bank sampah yang sudah terbentuk. Berdasarkan sumber(Karuniastuti, 2013), terdapat berbagai alternatif pengembangan bank sampah sebagai contoh, pengembangan bank sampah menjadi unit usaha simpan pinjam, unit usaha sembako, koperasi bank sampah, hingga pinjaman modal usaha(Wedayani, 2018). Namun, pengembangan yang akan dilakukan nanti hanya akan dilakukan kepada salah satu alternatifnya saja tergantung kebutuhan dari mitra(Susanto and Asmira, 2017).

Terdapat 2 metode yang digunakan pada kegiatan ini antara lain:

\section{Pendidikan Masyarakat:}

a. Sosialisasi awal tentang bank sampah, meliputi definisi dari bank sampah, tujuan dari pembentukan bank sampah, dan juga manfaat yang didapat dari bank sampah baik itu manfaat yang diterima langsung oleh warga banjar dan juga manfaat bagi kelestarian dan kebersihan lingkungan sekitar banjar. Sosialisasi ini akan diberikan kepada seluruh anggota ST. Kertha Budi Luhur dan juga warga banjar Kayumas Kelod. Narasumber dari sosialisasi adalah perusahaan daur ulang sampah.

b. Sosialisasi tentang kepedulian lingkungan terutama pengelolaan sampah dan juga tata cara pengolahan sampah kepada masyarakat banjar Kayumas Kelod.

c. Sosialisasi pengolahan sampah dan pemanfaatan bank sampah sebagai media pengelolaan sampah melalui media sosial yaitu Instagram, Facebook, dan Twitter.

\section{Pelatihan}

Pada metode ini, pelatihan teknis yang ditujukan bagi calon pengurus bank sampah baik itu dari organisasi ST. Kertha Budi Luhur dan juga dari warga banjar, dimana pelatihan ini mencakup tentang bagaimana cara membentuk bank sampah, 
cara mengelola operasional bank sampah, mulai dari memilah sampah sampai dengan bekerja sama dengan pengepul sampah. Pada tahap ini penulis bekerja sama dengan narasumber dari perusahaan daur ulang sampah.

\section{HASIL DAN PEMBAHASAN}

Beberapa kegiatan pada bab ini terdiri dari sejumlah tahapan, yaitu: Rapat Teknis Tim dengan pengurus ST Kerta Budi Luhur, Sosialisasi dan Pelatihan.

\section{Rapat Teknis Tim dengan Pengurus ST Kerta Budi Luhur}

Kegiatan awal yang dilakukan adalah mengadakan rapat teknis antara Tim pengabdian dan Pengurus ST Kerta Budi Luhur terkait dengan sosialisasi dan pelatihan yang akan dilaksanakan.

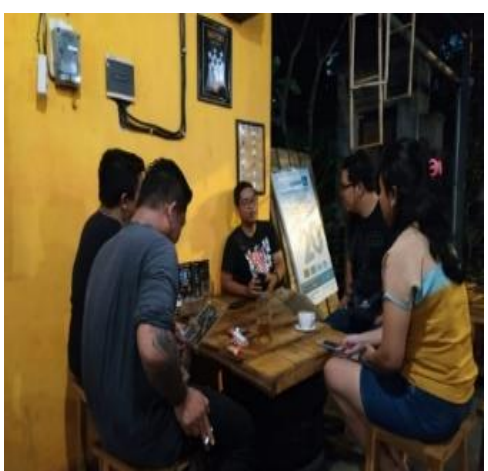

Gambar 6. Rapat Teknis antara Tim Pengabdian dengan Pengurus ST. Kerta Budi Luhur

Pada rapat tersebut membahas tentang waktu, tempat dan teknis serta narasumber pada kegiatan sosialisasi dan pelatihan.

\section{Sosialisasi}

Sosialisasi yang bertemakan kepedulian lingkungan ini dihadiri sedikitnya 25 peserta dari ST. Kerta Budi Luhur. Sebagai narasumber pada kegiatan sosialisasi ini adalah Bapak I Gusti Putu Semara Putra yang merupakan pengurus Asosiasi Bank Sampah Indonesia (ASOBSI) Denpasar.

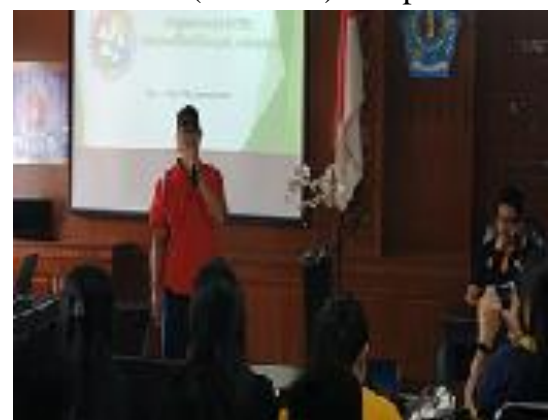

Gambar 7. Kegiatan Sosialisasi Bank Sampah
Pada saat itu juga dilaksanakan kegiatan sosialisasi pemanfaatan social media sebagai media promosi program kerja dari ST. Kerta Budi Luhur yang disampaikan oleh Tim pengabdian.

Kegiatan diakhiri dengan penyerahan piagam dan foto bersama antara narasumber, tim dan Pengurus ST. Kerta Budi Luhur

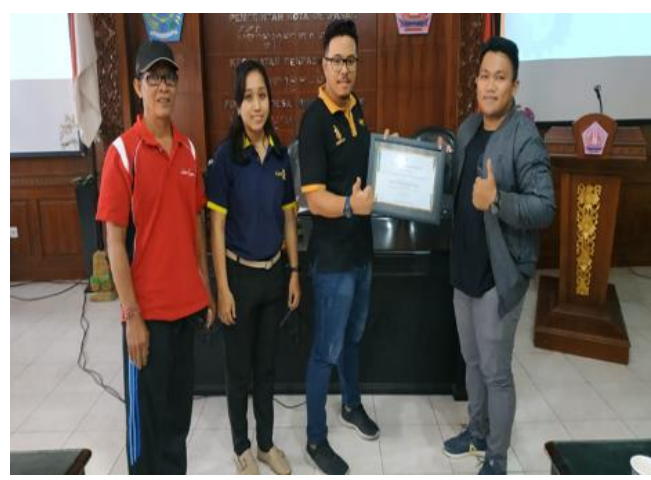

Gambar 8. Penyerahan Piagam

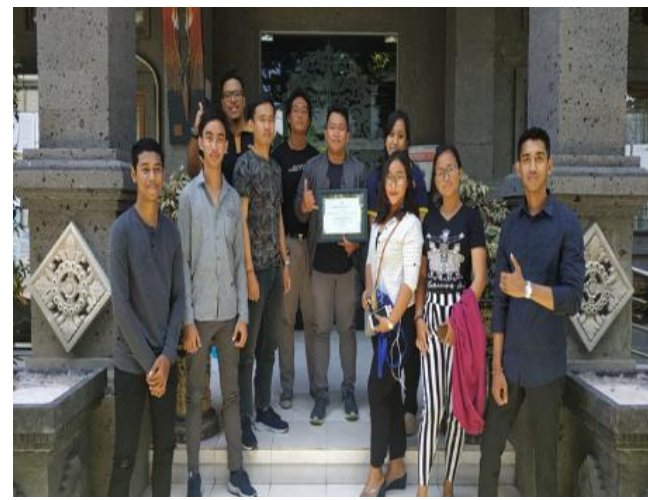

Gambar 9. Foto Bersama dengan Pengurus ST Kerta Budi Luhur

\section{Pelatihan}

Kegiatan selanjutnya adalah tentang pelatihan pemanfaatan sosial media sebagai media promosi dari salah satu program kerja ST. Kerta Budi Luhur.

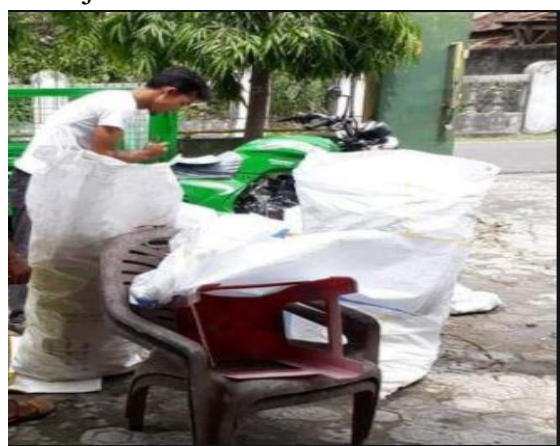

Gambar 10. Seorang anggota ST Kerta Budi Luhur dalam memilah sampah 
Pada Gambar 10 tampak salah sorang anggota ST. Kerta Budi Luhur dalam memilah sampah yang nantinya akan dibawa ke bank sampah.

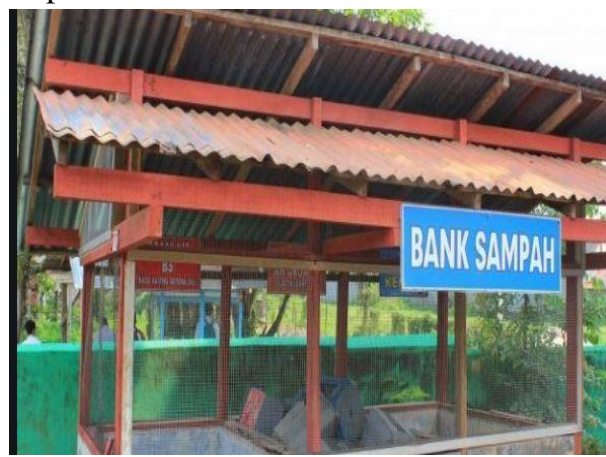

Gambar 11. Bank Sampah Hasil Swadaya ST. Kerta Budi Luhur

Bank sampah hasil Swadaya dari ST. Kerta Budi luhur, tampak pada Gambar 11. Bank sampah tersebut dikerjakan setelah dari hasil diskusi dengan pengurus ASOBSI Denpasar.

Selain dokumentasi pada Gambar 10 dan Gambar 11, ST. Kerta Budi Luhur juga membuat konten pada sosial media mereka yang tampak pada Gambar 12 dibawah ini.

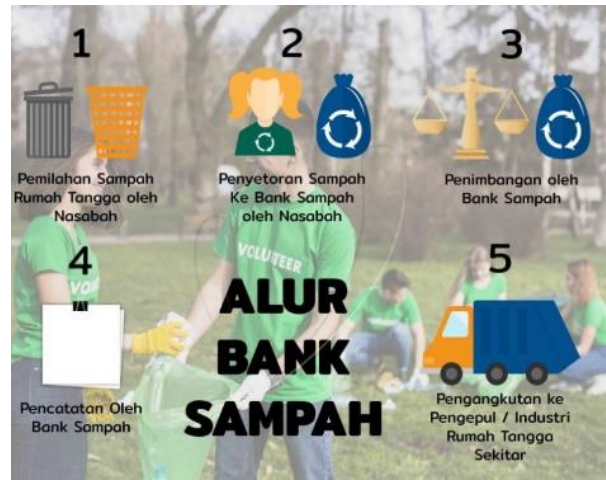

Gambar 12. Salah Satu Konten Pada Media Sosial ST Kerta Budi Luhur

\section{KESIMPULAN}

Terdapat beberapa kesimpulan pada kegiatan pengabdian kali ini. Beberapa kesimpulan tersebut antara lain:

1. Kegiatan Sosialisasi tentang bank sampah yang dimana merupakan salah satu Program Kerja dari ST. Kerta Budi Luhur berjalan sesuai target dimana mampu menghadirkan sedikitnya 25 orang pada kegiatan tersebut.

2. Bank Sampah telah berhasil dibuat berdasarkan atas swadaya dari anggota ST. Kerta Budi Luhur dan diskusi dengan pengurus ASOBSI kota Denpasar.

3. ST. Kerta Budi Luhur mampu membuat konten pada sosial media mereka untuk promosi dari salah satu program kerja mereka yaitu kepedulian pada lingkungan. Peningkatan kesadaran manajemen pengelolaan sampah sebesar $85 \%$ anggota ST. Kertha Budi Luhur setelah dilakukannya pelatihan.

\section{UCAPAN TERIMAKASIH}

Dalam penyusunan jurnal ini, penulis banyak memperoleh petunjuk dan bimbingan dari berbagai pihak. Sehubungan dengan hal tersebut pada kesempatan ini penulis menyampaikan ucapan terima kasih kepada:

1. Bapak Dr. Dadang Hermawan., selaku Rektor ITB STIKOM Bali.

2. Bapak Narasumber yaituI Gusti Putu Semara Putra selaku Pengurus ASOBSI Kota Denpasar

3. Rekan Rekan ST Kerta Budi Luhur.

4. Rekan-rekan pada bagian Dirakakem, Prodi, lab dan LP2M.

5. Rekan-rekan Mahasiswa yang membantu pada saat pelaksanaan.

\section{DAFTAR PUSTAKA}

Asteria, D. and Heruman, H. (2016) 'Bank Sampah Sebagai Alternatif Strategi Pengelolaan Sampah Berbasis Masyarakat di Tasikmalaya', Jurnal Manusia dan Lingkungan, 23(1), p. 136.

I.K. Agus. (2016) 'Optimalisasi Peran Sekaa Teruna Teruni(Organisasi Kepemudaan Berbasis Kearifan Lokal di Bali )Bahaya Plastik terhadap Kesehatan dan Lingkungan', Swara Patra: Majalah Pusdiklat Migas, 3(1), pp. 6-14.

Karuniastuti, N. (2013) 'Bahaya Plastik terhadap Kesehatan dan Lingkungan', Swara Patra: Majalah Pusdiklat Migas, 3(1), pp. 614.

Padmiari, I.A, Sugiani, Pande Putu, Gumala, Ni Made, O., Provinsi, D. and Klungkung, K. (2015) 'DALAM PEMBERIAN ASI EKSLUSIF DI KABUPATEN KLUNGKUNG , PROVINSI BALI , TAHUN 2014 ( Empowering Sekaa Teruni on Assisting Pregnant Mothers for Giving Exclusive Breastfeeding in Klungkung, Bali , 2014 )', 2014(17), pp. 321-328.

Susanto, A. and Asmira (2017) 'Perancangan Website Sebagai Media Promosi dan Informasi Menggunakan Metode Web Engineering', Simkom, 2(3), pp. 9-17. doi: 10.51717/simkom.v2i3.23.

Utami, E. (2013) 'Buku-Panduan-Sistem-Bank-Sampah-10-KisahSukses-Ina-Id_Tcm1310-514974 Id.Pdf’. Available at https://www.unilever.co.id/id/Images/buku-panduan-sistembank-sampah-10-kisah-sukses-ina-id_tcm1310-514974_id.pdf.

Wedayani, N. M. (2018) 'Studi Pengelolaan Sampah Plastik Di Pantai Kuta Sebagai Bahan Bakar Minyak', Jurnal Presipitasi : Media Komunikasi dan Pengembangan Teknik Lingkungan, 15(2), p. 122. doi: 10.14710/presipitasi.v15i2.122-126. 